\title{
Treatment of periodontal infections due to anaerobic bacteria with short-term treatment with metronidazole
}

\author{
W. J. Loesche, S. A. Syed, E. C. Morrison, B. Laughon and N. S. Grossman \\ University of Michigan, School of Dentistry, Ann Arbor, Michigan, U.S.A.
}

\begin{abstract}
In the present report, five selected periodontal patients were treated for 1 week with metronidazole. Two of the patients had their teeth scaled and root-planed the week they received metronidazole. Prior to treatment, $B$. asaccharolyticus accounted for $41 \%$ of the cultivable isolates and the spirochetes averaged $29 \%$ of the microscopic count in plaque removed from each of four pockets per patient. The presence of these elevated proportions of periodontopathic bacteria combined with the presence of periodontal pockets and attachment loss suggested that the patients were in a state of an active infectious process involving primarily anaerobic bacteria. If this be the case, then antimicrobial therapy directed against these anaerobes with metronidazole was indicated. The 1-week treatment with metronidazole significantly reduced the proportions of these organisms for up to 6 months after treatment. Coincident with these findings was an improvement in the clinical parameters, especially in those sites that initially had greater than $5 \mathrm{~mm}$ pocket or attachment loss. These sites showed a $2 \mathrm{~mm}$ or more reduction in pocket depth and an almost $2 \mathrm{~mm}$ gain in apparent attachment that was evident 6 months after treatment. The results obtained were in only five patients. However, the magnitude of improvement suggests that antimicrobial therapy directed against anaerobic organisms may be a valuabie adjunct to periodontal therapy.
\end{abstract}

Bacteriological investigations of plaques taken from various periodontal disease entities indicate that absolute and/or relative increases in presumably indigenous organisms are associated with the disease state (Loesche 1976a, Socransky 1977). An increase in spirochetes, especially of the intermediate and large sizes, was seen in acute necrotizing ulcerative gingivitis (ANUG) (Listgarten \& Lewis 1967) and in periodontitis (Listgarten \& Helldén 1978, Keyes et al. 1978); an increase in Bacterioides asaccharolyticus was observed in advanced periodon- titis (Slots 1977); an increase in gliding saccharolytic rods, including Capnocytophaga species, was found in juvenile periodontitis (Newman \& Socransky 1977); collagenaseproducing Bacillus cereus strains were isolated from periodontitis in trisomy 21 patients (Loesche et al. 1974); Actinomyces viscosus increased in experimental gingivitis (Loesche \& Syed 1978) and possibly in chronic periodontitis (Williams et al. 1976); Bacteroides melaninogenicus ss. intermedius increased during pregnancy gingivitis (Kornman \& Loesche 1980); and Actinobacillus 
actinomycetemcomitans and Eikenella corodens increased in active periodontitis (Tanner et al. 1979). All of these species, with the exception of the untested spirochetes, cause periodontal pathology in the germfree rodent (Socransky 1977).

These findings individually and collectively lend support for the specific plaque hypothesis which states that only certain plaques cause "periodontal infections" due to the presence of one or more pathogens and/ or to a relative increase in the levels or proportions of one or more potentially periodontopathic organisms (Loesche 1976a). The presence of discrete microbial profiles associated with many of the above clinical entities suggests that definitive treatment should be aimed towards the elimination and/or suppression of the suspected periodontopathic organism(s). The nature of this definitive treatment is in a state of evolution, but would include intensive mechanical plaque control procedures (Lindhe \& $\mathrm{Ny}$ man 1975, Rosling et al. 1976a, Rosling et al. 1976b, Axelsson \& Lindhe 1978, Knowles et al. 1979), as well as the judicious usage of antimicrobial agents. Topical antimicrobials will improve the gingival health and reduce plaque accumulations (Löe \& Schiott 1970, Loesche \& Nafe 1973), but apparently, are not able to effectively penetrate the pocket sites and alter the levels of periodontopathic organisms contained therein. This reservoir of periodontopathic organisms conceivably could be eliminated by systemic antibiotics and/or by delivery of an antimicrobial agent directly into the pocket either by irrigating devices (Keyes et al. 1978), or by hollow fiber device (Goodson et al. 1979).

Several studies suggest that systemically administered tetracyclines either alone or in conjunction with mechanical treatment can change the profile of the pocket flora from a predominantly Gram-negative flora to a predominantly Gram-positive flora (Listgarten et al. 1978, Osterberg et al. 1979,
Slots et al. 1979, Williams et al. 1979). The clinical findings "revealed that the administration of tetracycline had only a minor effect on the parameters examined" (Helldén et al. 1979). Other systemic antimicrobials have not received similar clinical trials. One potentially useful systemic agent is metronidazole (Flagyl ${ }^{\circledR}$ ), an antiprotozoal agent that has a unique spectrum of activity against anaerobic bacteria, including such periodontopathic organisms as $B$. asaccharoiyticus and the various spirochete species (Sutter \& Finegold 1977, Chow et al 1977, Davies et al. 1964). Metronidazole is remarkably effective in the treatment of ANUG (Shinn 1962, Duckworth et al. 1966), but apparently has not been used in humans for the treatment of the various forms of periodontitis. In beagle dogs, a 28-day treatment with metronidazole decreased plaque, prevented the development of gingivitis and maintained a plaque flora dominated by coccal and rod forms, i.e. a nondiseaseassociated flora (Heijl \& Lindhe 1979).

In the present report, five selected periodontal patients were treated for 1 week with metronidazole. Various bacteriological and clinical parameters were monitored periodically for 6 or more months following the initial treatment.

\section{Material and Methods}

Patients. All patients were medically healthy, and all but one had no recollection of recent antibiotic usage. Patient $D$ had received antibiotics several times in the immediately preceding 6 -month period for recurrent periodontal abscesses. All patients were advised of the mutagenicity of metronidazole in bacterial systems (Rosenkranz \& Speck 1977), and of its adverse reaction with alcohol consumption. They were told that the usage of metronidazole in periodontal infections was experimental and that we were investigating this usage 
under an investigational new drug exemption from the Food and Drug Administration (FDA).

Treatment schedule. Patients $\mathrm{D}, \mathrm{L}$, and $\mathrm{H}$ were given 21 tablets of metronidazole (Flagyl, $250 \mathrm{mg}$, G. D. Searle Co.), and advised to take one tablet three times a day for 7 days. Patients $E$ and $R$ were given the same tablets and instructions, but had onehalf of the dentition scaled and root-planed on the first day of metronidazole therapy, and the other half scaled and root-planed on the last day of metronidazole therapy. No oral hygiene instructions were provided, nor were patients given any additional mechanical therapy during the 6- to 8-month period of observation, with one exception. Patient $\mathrm{H}$ received a thorough scaling and root-planing of the maxillary dentition approximately $22-25$ weeks after she finished her I week of metronidazole therapy.

Bacteriological procedures. Plaque was removed from one periodontal pocket per quadrant in each patient for a total of four samples per patient. The sites chosen appeared from X-ray examination to be the most severely involved in each quadrant and were usually about molar teeth. The marginal plaque about the site was removed with a curette and discarded. The curette was introduced into the pocket and extended as far apically as possible. The root surface was then scaled, and the adherent plaque on the scaler tip was transferred to a vial containing $4 \mathrm{ml}$ of reduced transport fluid (RTF) without EDTA (Loesche et al. 1972). A second plaque sample from the same site was added to $0.3 \mathrm{ml}$ physiological saline with $1 \%$ gelatin (Listgarten \& Helldén 1978), and used for the microscopic enumeration of spirochetes. The first plaque sample was immediately placed within the anaerobic chamber, sonically dispersed for $20 \mathrm{sec}$ with a Kontes sonifier (Vineland,
NJ), serially diluted in RTF and plated automatically with a spiral plater (Spiral Systems, Inc., Cincinnati, Ohio), on a variety of nonselective and selective agar media. This dispersal procedure appears to give optimal recoveries of Gram-negative organisms from plaque samples (Syed \& Loesche 1978). Concurrent studies with this methodology revealed that the percent recovery of viable organisms from periodontal samples averaged about $65 \%$ of the microscopic count (Kornman, unpublished data). The total count and the $B$. asaccharolyticus counts were obtained from growth on enriched Trypticase soy agar (ETSA) (Syed et al. 1980). Representative brown-black colonies were Gram stained and tested for glucose fermentation. There was no difficulty in distinguishing $B$. asaccharolyticus by colony morphology from the red-brown pigmented colonies of Actinomyces odontolyticus.

The second plaque sample was dispersed by vortexing, and aliquots were viewed by dark-field microscopy. Either 200 organisms or the number of organisms in 20 high power fields (hpf) were enumerated, depending on which event occurred first. The number of spirochetes per $10 \mathrm{hpf}$ are reported, as welli as the percent of the spirochetes in the microscopic sampie. Thie detailed cultural and microscopic findings for each site will be presented in a separate report.

Clinical examinations. The number of papillary bleeding sites and the magnitude of the bleeding were assessed so as to give a papillary bleeding score (PBS) (Loesche 1980). The method used was a modification of the sulcular bleeding index of Mühlemann \& Son (1971), and consisted of a subjective estimate of the amount of bleeding which occurred from a papillary site after the insertion of a Stim-U-Dent toothpick. All teeth, including molars with furcation involvement, were scored for pocket depth 
and loss of attachment using procedures previously described (Ramfjord 1967). All readings were obtained by one individual (EM).

Statistics. The various measurements were repeated at intervals following the 1-week treatment. These were compared with the pretreatment values by the paired t-test.

\section{Results}

The findings will be presented in the form of a case report for each patient.
Patient $D$ was a 48 -year-old white female whose periodontal health had progressively deteriorated in the preceding 5-year period. Upper arch extractions had been recommended, but the patient hesitated to have this done. She had a history of periodontal abscesses that were managed by local debridement and systemic antibiotics. At the initial examination, 16 sites had pockets ranging from 6 to $9 \mathrm{~mm}$ in depth and another 51 sites had pockets ranging from 3 to $5 \mathrm{~mm}$ in depth. Twenty-five sites had 6 to $8 \mathrm{~mm}$ attachment loss, and another 49 sites had 3 to $5 \mathrm{~mm}$ attachment loss. The

Table 1. Effect of 1 week of metronidazole treatment on clinical and bacteriological parameters: Patient D, age 48: Terminal pertodontitis

Der Effekt einer Woche Metronidazolbehandlung hinsichtlich klinischer und bakteriologischer Parameter: Patient D, 48 Jahre alt: terminale Parodontitis

Action d'une semaine de traitement au métronidazole sur les paramètres cliniques et bactériologiques: patient $D$, âgé de 48 ans; parodontite au stade terminal

\begin{tabular}{l} 
Preatment \\
\cline { 3 - 7 }
\end{tabular}


molar teeth had furcation involvement. The papillary bleeding score was 22 , indicative of mild gingivitis. $B$. asaccharolyticus accounted for $35 \%$ of the cultivable flora from the four sample sites. Spirochetes were present, but were outnumbered by other organisms observed in the dark-field examination (Table 1).

The 1-week metronicazole treatment significantly reduced either the proportions or levels of $B$. asaccharolyticus for at least 19-38 weeks after treatment (Table 1). Seventy-two weeks after treatment the $B$. asaccharolyticus proportions had increased to $20 \%$, but CFUs of $B$. asaccharolyticus were slightly elevated compared to the pretreatment values. The levels of spirochetes were reduced at 0 and 6 weeks, but returned to pretreatment values by 19 weeks. The decrease in pocket depth, as well as the change in apparent attachment distance from the pretzeatment values, were calculated for each recall visit. The results achieved in the most severely involved sites are shown in Table 1. The metronidazole treatment was associated with a $1.6-1.8 \mathrm{~mm}$ reduction in pocket depth during the 72 week period following treatment. There was an apparent gain in attachment of $1.5 \mathrm{~mm}$ during the first 26 weeks, a $1.2 \mathrm{~mm}$ gain at 38 weeks, and a $0.9 \mathrm{~mm}$ gain after 72 weeks (Table 1). This patient did not receive any additional periodontal therapy during this 72-week period, but had taken antibiotics on one occasion for medical reasons.

Patient $L$ was a 17 -year-old black female who had had all first molars and maxillary incisors extracted in the previous year. $X$ rays taken at that time indicated that this patient exhibited classic molar-incisor ju-

Table 2. Effect of 1 week of metronidazote treatment on clinical and bacteriological parameters. Patient L, age 17; Residual juvenile periodontitis ${ }^{\mathrm{B}}$

Der Effekt einer Woche Metronidazoibehandlung auf klinische und bakteriologische Parameter. Patient L.; 17 Jahre alt; residuale juvenile Parodontitis

Action d'une semaine de traitement au métronidazole sur les paramètres cliniques et bactériologiques: patient $L$, âgé de 17 ans; parodontite juvénile résiduelle

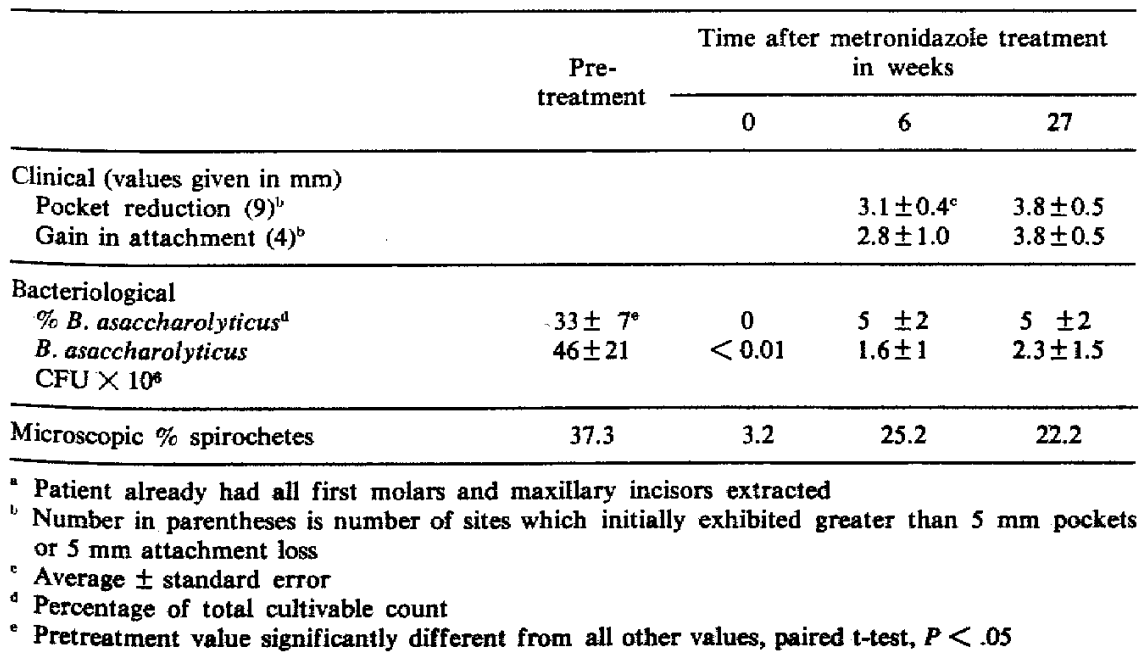


Table 3. Effect of 1 week of metronidazole treat ment on clinical and bacteriological parameters. Patient $\mathrm{H}$, age 28; Advanced periodontitis

Der Effekt einer Woche Metronidazolbehandlung auf klinische und bakteriologische Parameter. Patient H., 28 Jahre alt; fortgeschrittene Parodontitis

Action d'une semaine de traitement au métronidazole sur les paramètres cliniques et bactériologiques: patient $H$, âgé de 28 ans; parodontite à un stade avancé

\begin{tabular}{|c|c|c|c|c|c|}
\hline & \multirow{2}{*}{$\begin{array}{c}\text { Pre- } \\
\text { treatment }\end{array}$} & \multicolumn{4}{|c|}{ Time after metronidazole treatment in weeks } \\
\hline & & 0 & 13 & 20 & 33 \\
\hline $\begin{array}{l}\text { Clinical (value given in mm) } \\
\text { Pocket reduction }(49)^{\mathrm{a}} \\
\text { Gain in attachment }(18)^{\mathrm{a}}\end{array}$ & & $\begin{array}{l}1.7 \pm 0.1^{\mathrm{b}} \\
1.1 \pm 0.3^{2}\end{array}$ & $\begin{array}{l}2.3 \pm 0.1 \\
1.4 \pm 0.3\end{array}$ & $\begin{array}{l}1.5 \pm 0.1 \\
1.1 \pm 0.2\end{array}$ & $\begin{array}{l}2.3 \pm 0.1^{c} \\
1.1 \pm 0.3^{c}\end{array}$ \\
\hline $\begin{array}{l}\text { Bacteriological } \\
\text { \% B. asaccharolyticus } \\
\text { B. asaccharolyticus } \times 10^{8}\end{array}$ & $\begin{array}{l}34 \pm 12 \\
15 \pm 9\end{array}$ & 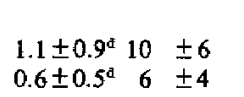 & $\begin{array}{l}15 \pm 6 \\
10 \pm 6\end{array}$ & $\begin{array}{r}16 \pm 8 \\
4 \pm 3\end{array}$ & $\begin{array}{l}26 \pm 13 \\
10 \pm 9\end{array}$ \\
\hline $\begin{array}{l}\text { Microscopic } \\
\text { spirochetes/10 hpfr } \\
\% \text { Spirochetes }\end{array}$ & $\begin{array}{r}190 \pm 83 \\
37 \pm 9\end{array}$ & $\begin{array}{lr}0.3 \pm 0.3^{\mathrm{d}} & 2.7 \pm 2 \\
0.5 \pm 0.5^{\mathrm{d}} & 10 \quad \pm 6\end{array}$ & $\begin{array}{ll}12 & \pm 8 \\
36 & \pm 7\end{array}$ & $\begin{array}{l}62 \pm 34 \\
24 \pm 7\end{array}$ & $\begin{array}{l}17 \pm 16 \\
13 \pm 5\end{array}$ \\
\hline $\begin{array}{l}\text { Number in parentheses is } \\
\text { or } 5 \mathrm{~mm} \text { attachment loss } \\
\text { - Average } \pm \text { standard error } \\
\text { - Teeth were scaled and cur } \\
\text { - Values are significantly dif } \\
\text { - Percentage of total cultiva } \\
\text { hpf = high power field }\end{array}$ & $\begin{array}{l}\text { aber of sites } \\
\text { d during w } \\
\text { nt from pre } \\
\text { count }\end{array}$ & $\begin{array}{l}\text { s which initially exh } \\
\text { eeks } 22-25 \text {. }\end{array}$ & $\begin{array}{l}\text { hibited gre } \\
\text { ired t-test, }\end{array}$ & $\begin{array}{l}\text { eater than } \\
P<.05\end{array}$ & (n) \\
\hline
\end{tabular}

venile periodontitis. When seen at the initial examination, the premolars and molars abutting the edentulous molar space exhibited bone loss and deep pockets, prompting us to make a diagnosis of residual juvenile periodontitis. $B$. asaccharolyticus accounted for $33 \%$ of the cultivable flora and averaged about 46 million colonyforming units (OFU) per pocket. One week of metronidazole treatment significantly reduced the proportions and levels of $B$. asaccharolyticus over the next 27-week period (Table 2). The spirochetes averaged about $37 \%$ of the microscopic count prior to treatment. The 1-week therapy with metronidazole caused an immediate 10 fold decrease in their proportions followed by a return at 6 and 27 weeks to about $25 \%$ of the microscopic count. The nine deep pockets showed an average reduction of $3.8 \mathrm{~mm}, 27$ weeks after therapy. The four sites which initially had $6 \mathrm{~mm}$ or more attachment loss had an apparent gain of $3.8 \mathrm{~mm}$ in attachment at the 27 -week recall visit (Table 2). This patient neither received periodontal therapy nor took antibiotics for medical reasons during this 27 -week period.

Patient $H$ was a 28 -year-old black female who had had maxillary first molars and maxillary incisors extracted while in her teens. She believed that the extractions were because of "gum disease". When seen by us, she had advanced periodontitis with furcation involvement of some molars. Forty-nine sites had pockets ranging from 6 to $10 \mathrm{~mm}$, and 18 sites exhibited attachment loss of 6 to $9 \mathrm{~mm}$. B. asaccharolyticus accounted for $34 \%$ of the cultivable flora 
Table 4. Effect of 1 week of metronidazole treatment and scaling on clinical and bacteriological parameters. Patient E, age 21; Advanced periodontitis

Der Effekt einer Woche Metronidazolbehandlung und von Zahnsteinbehandlung auf klinische und bakteriologische Parameter. Patient E., 21 Jahre alt; fortgeschrittene Parodontitis

Action d'une semaine de traitement au métronidazole avec détartrage sur les paramètres cliniques et bactériologiques: patient $E$, âgé de 21 ans; parodontite à un stade avancé

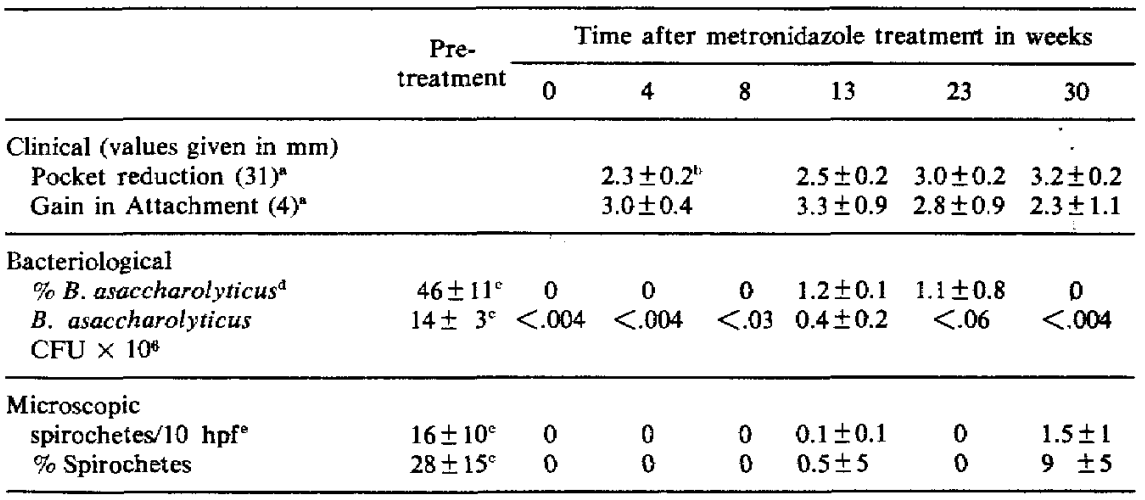

a Number in parentheses is number of sites which initially exhibited greater than $5 \mathrm{~mm}$ pockets or $5 \mathrm{~mm}$ attachment loss

" Average \pm standard error

c Pretreatment values significantly different from all other values, paired $t$-test, $P<.01$

d Percentage of total cultivable count

- hpf $=$ high power fields

and the various spirochetes for about $37 \%$ of the microscopic count (Table 3). Metronidazole treatment significantly decreased the proportions and levels of these organisms for at least 5 weeks. Thereafter, the proportions of both organisms gradually increased (Table 3). However, the absolute levels of spirochetes remained reduced by about $90 \%$, compared to the pretreatment value (Table 3 ). The pockets were reduced by $1.5-2.3 \mathrm{~mm}$ during the first 20 weeks, and there was an apparent increase in attachment of $1.1 \mathrm{~mm}$ (Table 3). The patient had received systemic tetracycline at week 11 for a medical infection. At weeks 22 25 , the patient received a thorough scaling and root-planing of her maxillary teeth which could account for the further pocket reduction and attachment gain noted at week 33. This mechanical therapy did not appear to affect the $B$. asaccharolyticus values, but might have lowered the spirochetal values (Table 3).

Patient $E$ was a 21-year-old black male who presented with a diffuse gingivitis and periodontitis. Four premolars had been extracted for orthodontic purposes. This patient had 31 pockets ranging from 6 to 10 $\mathrm{mm}$ in depth, but only in four of these sites was attachment loss greater than $5 \mathrm{~mm}$. $B$. asaccharolyticus averaged $46 \%$ of the cultivable flora, and the spirochetes accounted for $28 \%$ of the microscopic count (Table 4). An occasional amoeba was seen by dark-field microscopy. The patient was started on metronidazole and had the teeth 
Table 5. Effect of 1 week of metronidazole treatment and scaling on clinical and bacteriological parameters. Patient $R$, age 23; Early periodontitis

Der Effekt einer Woche Metronidazolbehandlung und von Zahnsteinbehandlung auf klinische und bakteriologische Parameter. Patient R, 23 Jahre alt; frühe Parodontitis

Action d'une semaine de traitement au métronidazole avec détartrage sur les paramètres cliniques et bactériologiques: patient $R$, âgé de 23 ans; parodontite à un stade précoce

\begin{tabular}{|c|c|c|c|c|c|}
\hline & \multirow{2}{*}{$\begin{array}{c}\text { Pre- } \\
\text { treatment }\end{array}$} & \multicolumn{4}{|c|}{ Time after metronidazole treatment in weeks } \\
\hline & & 0 & 5 & 17 & 21 \\
\hline $\begin{array}{l}\text { Climical (Values given in mm } \\
\text { Pocket reduction }(72)^{\mathrm{a}} \\
\text { Gain in attachment }(7)^{\mathrm{a}}\end{array}$ & & & $\begin{array}{c}0.3 \pm \quad .1^{\mathrm{b}} \\
0\end{array}$ & $\begin{array}{l}0.7 \pm 0.1 \\
0.7 \pm 0.6\end{array}$ & \\
\hline $\begin{array}{l}\text { Bacteriological } \\
\quad \% \text { B. asaccharolyticus } \\
\text { B. asaccharolyticus } \times 10^{a}\end{array}$ & $\begin{aligned} 61 & \pm 9 \\
151 & \pm 80\end{aligned}$ & $\begin{array}{l}2.4 \pm 1.6^{c} \\
0.4 \pm 0.3\end{array}$ & $\begin{array}{l}6.3 \pm 4^{\mathrm{v}} \\
1.5 \pm 1.2\end{array}$ & $\begin{array}{c}13 \pm 13 \\
0.2 \pm 0.2\end{array}$ & $\begin{array}{c}19 \pm 10 \\
7.4 \pm 6.4\end{array}$ \\
\hline $\begin{array}{l}\text { Mictoscopic } \\
\% \text { Spirochetes } \\
\text { Spirochetes } 10 \mathrm{hpf}\end{array}$ & $5.6 \pm 2$ & $\begin{array}{l}10 \\
1.4 \pm 0.9\end{array}$ & $\begin{array}{l}10 \\
15 \pm 11\end{array}$ & $1^{6} \pm 0.6$ & $\begin{array}{c}7 \\
4.8 \pm 3\end{array}$ \\
\hline
\end{tabular}

a Number in parentheses is number of sites which initially exhibited 3-5 mm pockets or 3-5 mm attachment loss

t Average \pm standard error

- Values are significantly different from pretreatment value.

d Percentage of total cultivable count

- hpf $=$ high power fields

on the right side scaled and root-planed. One week later the teeth on the left side were similarly treated. B. asaccharolyticus and the various spirochetes were essentially undetectable during the following 30-week period (Table 4). The 31 pockets that initially were greater than $5 \mathrm{~mm}$ were reduced by about $3 \mathrm{~mm}$ at week 30 . In the four sites that initially had greater than $5 \mathrm{~mm}$ attachment loss, there was an apparent gain in attachment of 2-3 mm (Table 4). No' mechanical treatment was given during this 30 -week interval, nor did the patient receive antibiotics for medical purposes during this time.

Patient $R$ was a 23 -year-old white male who presented with gingivitis and a diffuse periodontitis that included 72 sites that had 3-5 mm pockets, and two sites with $6 \mathrm{~mm}$ pockets. When the cultural studies showed that $B$. asaccharolyticus averaged $61 \%$ of the cultivable flora (Table 5), a diagnosis of active periodontitis was made. The patient was placed on metronidazole and the teeth were mechanically scaled in the same manner as described for patient $E$. The $B$. asaccharolyticus levels were reduced by over $90 \%$ and its proportions by over $60 \%, 21$ weeks after treatment (Table 5). There was a $0.7 \mathrm{~mm}$ pocket reduction and a $0.7 \mathrm{~mm}$ apparent gain in attachment, 17 weeks after treatment in the sites that initially exhibited 3-5 mm pockets or attachment loss (Table 5).

The mean values for the papillary bleeding score (PBS) in the time after metronidazole treatment for all patients are shown in Table 6. The 1-week metronidazole treatment significantly reduced the PBS by about $50-75 \%$ during the period of observation. Note that in the two older patients 
Table 6. Mean change in papillary bleeding score following l week of metronidazole treatment Mittlere Veränderung der Papillenblutung (Beurteilungseinheit, score) nach einer Woche Metronidazolbehandlung

Changements moyens dans les scores du saignement papillaire après une semaine de traitement au métronidazole

\begin{tabular}{lcccccc}
\hline & \multirow{6}{*}{$\begin{array}{c}\text { Pre- } \\
\text { treatment }\end{array}$} & \multicolumn{5}{c}{ Time after metronidazole treatment in weeks } \\
\cline { 3 - 7 } & & 0 & $4-10$ & $11-19$ & $20-29$ & $30-39$ \\
\hline Patient D & 22 & 10 & 8 & 10 & 12 & 10 \\
Patient L & 50 & 29 & 46 & & 27 & \\
Patient $\mathbf{H}$ & 22 & 7 & 11 & 6 & 16 & $2^{\mathrm{a}}$ \\
Patient $\mathrm{E}^{\mathrm{b}}$ & 58 & 26 & 4 & 10 & 17 & 15 \\
Patient $\mathbf{R}^{\mathrm{b}}$ & 38 & 21 & 19 & 11 & 16 & 18 \\
\hline Average/patient & $38 \pm 7^{\mathrm{c}}$ & $19 \pm 4$ & $18 \pm 8$ & $9 \pm 1$ & $18 \pm 3$ & $11 \pm 3$ \\
\hline
\end{tabular}

- Teeth were scaled and root planed during weeks 22-25

b Teeth were scaled and root planed while on metronidazole

- Pretreatment value significantly higher than all succeeding posttreatment values, paired $t$-test $P \leq 0.05$, with the exception of the 4-10 week interval

(D and $\mathrm{H}$ ), whose periodontitis included furcation involvement, the initial PBS was relatively low. In these patients the infec- tion was confined mostly to the apical areas of the pockets.

The profile of changes in the various

Table 7. Effect of 1 week of metronidazole treatment on various clinical and bacteriological parameters ( $\overline{\mathrm{x}} \pm$ stand. error)

Der Effekt einer Woche Metronidazolbehandiung auf verschiedene klinische und bakteriologische Parameter ( $\vec{x} \pm$ Standardirrtum)

Action d'une semaine de traitement au métronidazole sur divers paramètres cliniques et bactériologiques $(\bar{x} \pm$ erreur-type $)$

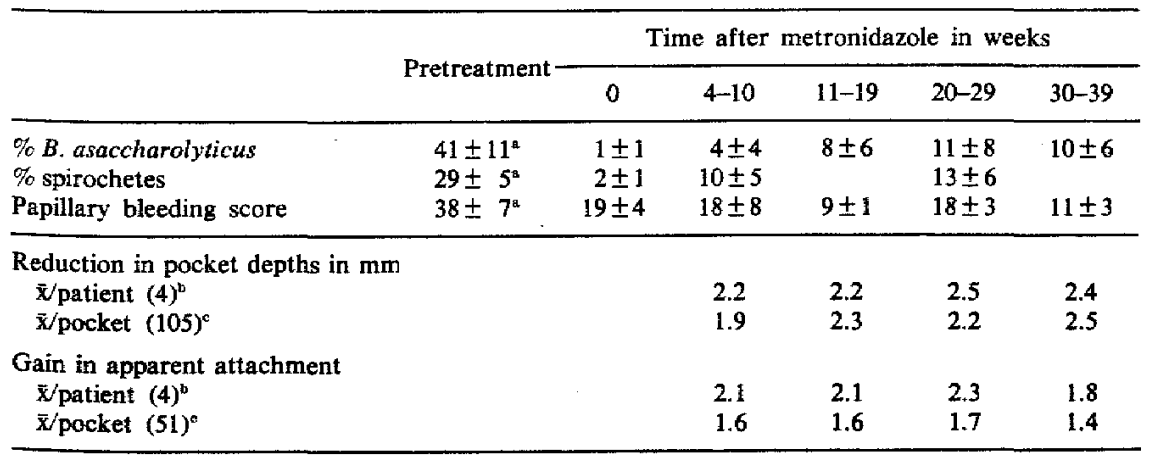

- Pretreatment value significantly higher than succeeding values $P<0.05$, paired t-test

b Number of patients

- Number of pockets 
clinical and bacteriological parameters for the five patients is summarized in Table 7 . Although the two patients who received the metronidazole during the period of scaling and root planing showed the greatest reduction in the PBS (Table 6), and responded optimally in regards to the other parameters, the numbers involved were too few to perform tests of significance between this group and those who received only metronidazole. As all five patients showed a similar improvement in the various parameters (Tables $1-5$ ), and as the mechanical treatment was minimal in the context of the patients' total treatment needs, the data for the five patients were grouped together and compared over time. The 1-week treatment with metronidazole with or without scaling significantly reduced the proportions of $B$. asaccharolyticus and spirochetes and reduced the PBS for at least 6 months after treatment (Table 7). The pockets that were initially greater than $5 \mathrm{~mm}$ were reduced by about $2.5 \mathrm{~mm}$. This was true if the average reduction was calculated per patient, or per pocket (Table 7). The apparent gain in attachment in those sites which initially exhibited greater than $5 \mathrm{~mm}$ attachment loss was about $1.8 \mathrm{~mm}$ when calculated per patient and $1.4 \mathrm{~mm}$ when calculated per pocket.

\section{Discussion}

The patients in the present study presented with clinical disease coincident with elevated proportions and levels of $B$. asaccharolyticus and spirochetes in plaques removed from periodontal pockets. B. asaccharolyticus accounted for $41 \%$ of the cultivable isolates, and the spirochetes averaged $29 \%$ of the microscopic count (Table 7). These proportions are high compared to what has been reported for plaques from periodontal patients (Socransky et al. 1962, Loesche et al. 1972), but are consistent with values found when active disease is suspected (Slots 1977, Listgarten \& Helldén 1978). These bacteriological findings combined with the clinical appearance of the periodontium suggested that the patients, or at least the sampled pockets, were in the state of an active infectious process involving primarily anaerobic bacteria. If this is the case, antimicrobial therapy directed against these anaerobes was indicated according to the specific plaque hypothesis (Loesche 1976a). In recent years, several antimicrobials have been recommended for treatment of anaerobic infections (Finegold 1977), but only one, metronidazole, has been used in the treatment of oral infections (Shinn 1977, Ingham et al. 1977). Metronidazole interacts with low-redox-potential electron transport proteins of the type normally found in anaerobes to form a derivative which exerts a killing action in the cell (Müller et al. 1977). Microaerophilic organisms such as $A$. viscosus, and the Capnocytophaga and Eikenella species that exhibit periodontal pathology in animal models (Socransky 1977) would be expected to be, or are resistant to this agent. Thus, the usage of metronidazole in these patients provided a probe that would selectively discriminate against the anaerobic species while leaving the various facultative and microaerophilic species unaffected. In this manner the relative contribution of the anaerobes to the observed periodontal pathology could be gauged. The efficacy of metronidazole against the plaque anaerobes in the present patients was assessed by following the proportions of $B$. asaccharolyticus and spirochetes in the plaques before and after treatment. These organisms were chosen as indicator organisms because both can be easily identified in plaque samples, both were present in high numbers, and both are suspected of being periodontopathic. Metronidazole should be without an appreciable effect in those instances in which 
the microaerophilic organisms are primarily responsible for the concurrent periodontal pathology.

The 1-week treatment with metronidazole caused an obvious improvement in the periodontal health of the most diseased sites in each of these five patients. This was manifested by the greater than $50 \%$ reduction in the PBS (Table 6), a $2 \mathrm{~mm}$ or more reduction in pocket depth (Table 7), and an almost $2 \mathrm{~mm}$ gain in apparent attachment (Table 7) that were evident 6 months after treatment. These deep pockets would be expected to show the greatest improvement following a therapeutic regimen (Knowles et al. 1979). The magnitude of the improvement is surprising, considering that no efforts were made to instruct the patients in oral hygiene procedures and a minimal amount of mechanical debridement was used. This latter consisted of scaling and root planing in patients $E$ and $R$ during the week they were on metronidazole and scaling and root planing the maxillary teeth of patient $\mathrm{H}, 22$ to 25 weeks after she received metronidazole. These mechanical procedures contributed to the improvement of the periodontal condition, as patient E exhibited the best response to treatment of all the patients, and patient $\mathbf{H}$ showed reductions in the PBS and pocket depth as well as an attachment gain in the interval following scaling and root planing.

The persistent decline in numbers and proportions of $\boldsymbol{B}$. asaccharolyticus and spirochetes coincident with the sustained improvement in periodontal health argues that these bacterial types were contributing to the observed periodontal pathology. This is consistent with the long-known association of spirochetes (Loesche 1976b) and B. melaninogenicus (MacDonald et al. 1962) with periodontal disease. However, this finding is not synonymous with saying that these organisms initiated the disease or are the only organisms contributing to the disease.
Clearly in a complex anaerobic flora of the type found in periodontal pockets, other organisms or microbial interactions not detected by the present methodology could be of etiologic significance. The results suggest that the microaerophilic and facultative species present in these plaques were not primarily responsible for signs of disease observed.

Other investigators have monitored the clinical and bacteriological response to systemic tetracycline combined with various scaling and root-planing schedules (Listgarten et al. 1979, Helldén et al. 1979, Slots et al. 1979), or to locally administered tetracycline (Lindhe et al. 1979). The magnitude of clinical improvement attained appears to be that which can be achieved by repeated scaling (Helldén et al. 1979, Slots et al. 1979). The degree of improvement observed at 6 months in the five patients given metronidazole, especially as it relates to apparent attachment gain, is beyond that observed with tetracycline. The apparent superiority of metronidazole relative to tetracycline probably resides in metronidazole's unique spectrum of activity against anaerobes.

Some mention should be made concerning the significance of the apparent gain in attachment. In the absence of evidence that bone had regenerated and/or that anatomical reattachment had occurred, this measurement can only imply an apparent gain in attachment. It most likely reflected that the inflammation in the apical portion of the pocket had been reduced to the extent that the epithelium formed a tight cuff about the root surface. Accordingly, the periodontal probe that was used in a standard manner (Ramfjord 1967) could not penetrate as deeply in the pocket after treatment as before treatment (Armitage et al. 1977, Listgarten et al. 1976). The measurement thus gives some indication of tissue response at the apical extent of the 
pocket. The observation that metronidazole caused an apparent gain in attachment of about $1.5 \mathrm{~mm}$ in the sites with the most advanced signs of periodontal disease is encouraging.

The treatment and/or management of periodontal disease has, as its fundamental principle, the control of the bacterial flora in the periodontal pocket. Surgical procedures, if supplemented with periodic scaling and root planing, will effectively control this flora and restore periodontal health (Rosling et al. 1976a, b, Knowles et al. 1979). However, if these surgical procedures are not supplemented with rigorous oral hygiene and maintenance therapy, periodontal health will relapse and actually result in attachment loss which can be detected as early as 6 months after surgery (Nyman et al. 1978). The requirement for maintenance therapy can be explained by the regrowth of a periodontopathic flora that needs to be periodically disrupted. The present results indicate that when this periodontopathic flora comprises anaerobes, it may be effectively reduced by a systemic antimicrobial agent. If this is so, then metronidazole or other agents with a similar spectrum of activity, when incorporated into a regular periodontal treatment schedule, may enhance and/or prolong the periodontal health seen at recall visits. With this in mind, a double-blind clinical trial of metronidazole or placebo in conjunction with a periodontal treatment schedule that would include root planing, curettage, and surgery has been initiated. The metronidazole, or placebo, is administered during the hygienic phase of therapy, approximately 6-8 weeks prior to the initiation of surgery in patients with advanced periodontal disease.

If the current documentation that certain forms of periodontal disease represent specific plaque infections can be sustained, then some form of antimicrobial therapy with chemical agents will be an inevitable future treatment possibility. The choice of drugs available in the United States will probably be limited to those which already have FDA approval. Currently, neither metronidazole nor tetracyclines have FDA approval for usage in periodontal infections, simply because this usage was never described in the original drug application. This does not prevent the prescription usage of these drugs in dentistry. The practitioner should thus be aware of the known risks of each drug. Tetracyclines cannot be tested in the standard bacterial mutagenicity assay because the indicator organisms are sensitive to it. However, the high percentage of tetracycline-resistant organisms found in plaques following tetracycline therapy (Hawley et al. 1980, Williams et al. 1979) raise the possibility that some of these resistant organisms could arise by mutation. Metronidazole is mutagenic in the Ames test (Rosenkranz \& Speck 1977). Lifetime ingestion of very high dosages of metronidazole, ie. 0.3 and $0.5 \%$ of the diet, increased the incidence of malignant lymphoma in female mice (Rustia \& Shubik 1972). The dosages used were about 3500 times the single course of treatment used in the present patients (Roe 1977). This study was complicated by the fact that the high-dose animals received oxytetracycline in the drinking water during two periods, each of 2 weeks' duration (Roe 1977). Subsequent mouse, rat and hamster studies have not shown metronidazole to be carciogenic (Roe 1977), and to be "probably no more than a weak tumorigen in mice after prolonged high-level exposure" (Rust 1977). A retrospective human study could find no evidence of carcinogenicity in female patients who had been prescribed metronidazole for the treatment of trichomonal vaginitis (Beard et al. 1979). This study encompassed over 8200 patient-years and included for some patients, 10-year follow-up data. These 
animal and human studies indicate that metronidazole should be used discriminately. Metronidazole's unique spectrum of activity against $B$. asaccharolyticus, spirochetes and other anaerobes involved in periodontal disease, coupled with the favorable clinical response to short-term treatment, indicate that this agent will have increased usage in dentistry. Efforts to find antimicrobials with a similar anaerobic spectrum such as nitrimidazine (Lozdan et al. 1971), but minus the mutagenic potential, should be pursued (Rosenkranz \& Speck 1977). Until that time metronidazole should be reserved for those instances in which the anaerobic nature of the infection is documented.

\section{Acknowledgments}

This investigation was funded by National Institute of Dental Research grants DE03011 and DE-02731. G. D. Searle, Chicago, Illinois kindly provided the Flagyl. Dr. Harry R. Pape and Janice Stoll provided valuable assistance in the collection of the data.

\section{Zusammenfassung}

Parodontale Intektionen durch anaerobe Bakterien - Behandlungsresultate mit Kurzzeitgaben von Metronidazol

Der vorliegende Bericht beschreibt 5 ausgewählte parodontalerkrankte Patienten, die eine Woche lang mit Metronidazol behandelt wurden. Bei 2 dieser Patienten wurde in der Woche, zusammen mit Metronidazolgaben, der Zahnstein entfernt und Wurzelplanung vorgenommen. Vor der Behandlung machte der Anteil des $B$. asaccharolyticus $41 \%$ der kultivierten Isolate aus, und der Anteil der Spirochaeten betrug etwa $29 \%$ bei mikroskopischer Zählung der Mikroorganismen in der Plaque einer jeden der 4 Zahnfleischtaschen, die bei jedem Patienten untersucht wurden. Die erhöhten Anteile an der parodontopathischen Bakterienflora, bei gleichzeitigem Vorhandensein parodontaler Taschen und dem Vorkommen von Attachmentverlust, liessen die Folgerung zu, dass diese Patienten sich im aktiven Stadium eines infektiösen Prozesses bei gleichzeitiger Anwesenheit primär anaerober Bakterien befanden. War diese Folgerung richtig, war antimikrobielle Therapie mit Metronidazol gegen diese Anaerobier angezeigt. Die Behandlung mit Metronidazol während einer Woche reduzierte den proportionalen Anteil dieser Organismen bis zu 6 Monaten nach der Behandlung. Gleichzeitig damit wurde eine Verbesserung klinischer Parameter gesehen, und das vor allem in den Regionen mit Zahnfleischtaschen, die tiefer als $5 \mathrm{~mm}$ waren und bei denen Attachmentverlust vorlag. In diesen Regionen verringerten sich die Taschentiefen um $2 \mathrm{~mm}$ oder mehr und 6 Monate nach der Behandlung war ein Gewinn an Attachment von $2 \mathrm{~mm}$ offenbar. Die hier erhaltenen Resultate wurden bei nur 5 Personen erreicht. Das Ausmass der Verbesserung lässt jedoch vermuten, dass antimikrobielle Therapie, gezielt auf anaerobe Organismen eingestellt, ein wertvolles Adjuvans zu parodontaler Therapie bedeuten kann.

\section{Résumé}

Le traitement à court terme au moyen du métronidazole dans les cas d'infections parodontales dues à des bactéries anaérobies. Compferendu de cinq cas

Le présent travail rend compte de cinq cas de parodontopathies que l'on a choisis et traités pendant une semaine au métranidazole. Chez deux des patients, les dents ont subi un détartrage et un polissage des surfaces radiculaires pendant la semaine où ils recevaient le traitement au métronidazole. Avant le traitement, B. asaccharolyticus représentait $41 \%$ des colonies isolées pouvant être cultivées et les spirochètes se montaient en moyenne à $29 \%$ dans les numérations microcospiques faites sur la plaque prẻlevée dans quatre culs-de-sac par patient La présence en proportions élevées de ces bactéries parodontopathiques, associée à la présence de culs-de-sac parodontaux et de perte de l'attachement, semble indiquer que les patients étaient sujets à un processus infectieux actif où participaient principalement des bactéries anaérobies. En supposant que ce soit le cas, un traitement antibactérien au métronidazole, dirigé contre ces anaérobies, était indiqué. Le traitement at métronidazole institué pendant une semaine a réduit significativement les proportions de ces organismes pendant une période allant jusqu'à six mois après le traitement. En concordance avec ces résultats, il se produisait une amélioration des paramètres cliniques, surtout au niveau des localisations 
où les culs-de-sac ou la perte de l'attachement étaient intialement de plus de $5 \mathrm{~mm}$. Ces localisations présentaient une réduction de la profondeur des culs-de-sac de $2 \mathrm{~mm}$ ou plus et une amélioration de presque $2 \mathrm{~mm}$ de l'attachement apparent, visible six mois après le traitement. Les résultats obtenus ont été constatés chez cinq patients seulement. Cependant, l'ampleur de l'amélioration semble indiquer qu'un traitement antimicrobien dirigé contre les organismes anaérobies peut représenter une aide de grande valeur pour le traitement parodontal.

\section{Relerences}

Armitage, G. C., Svanberg, G. K. \& Löe, H. (1977) Microscopic evaluation of clinical measurements of connective tissue attachment levels. Journal of Clinical Periodonto$\log y$ 4, 173-178.

Axelsson, P. \& Lindhe, J. (1978) Effect of controlled oral hygiene procedures on caries and periodontal disease in adults. Journal of Clinical Periodontology 5, 133-151.

Beard, C. M., Noller, K. L., O'Fatlon, W. M., Kurland, L. T. \& Dockerty, M. B. (1979) Lack of evidence for cancer due to use of metronidazole. New England Journal of Medicine 301, 519-522.

Chow, A. W., Bednorz, D. \& Guze, L. B. (1977) Susceptibility of obligate anaerobes to metronidazole: an extended study of 1,054 clinical isolates. In Metronidazole (S. Finegold, ed.) Proceedings of the International Metronidazole Conference, Montreal, Quebec, Canada, May 26-28, 1976. Excerpta Medica, 286-292.

Davies, A. H., McFadzean, J. A. \& Squires, S. (1964). Treatment of Vincent's stomatitis with metronidazole. British Medical Journal 1, 1149-\$150.

Duckworth, R., Waterhouse, J. P., Britton, D. E. R., Nuki, K., Sheiham, A. \& Winter, R. (1966) Acute ulcerative gingivitis. A double-blind controlled clinical trial of metronidazole. British Dental Journal 120, $599-602$.

Finegold, S. M. (1977) Current status of therapy anaerobic infections in humans. In Metronidazole (S. Finegold, ed.) Proceedings of the International Metronidazole Conference, Montreal, Quebec, Canada, May 26-28, 1976. Excerpta Medica, 273-278.

Goodson, J. M., Haffajee, A. \& Socransky,
S. S. (1979) Periodontal therapy by local delivery of tetracycline. Journal of Clinical Periodontology 6, 83-92.

Hawley, R., Lee, L. \& LeBlanc, D. (1980) Effects of tetracycline on the streptococcal flora of periodontal pockets. Antimicrobial agents. Chemotherapy 17, 372-378.

Heijl, L. \& Lindhe, J. (1979) The effects of metronidazole on the development of plaque and gingivitis in the beagle dog. Journal of Clinical Periodontology 6, 197-209.

Helldén, L. B., Listgarten, M. A. \& Lindhe, J. (1979) The effect of tetracycline and/or scaling on human periodontal disease. Journal of Clinical Periodontology 6, 222-230.

Ingham, H. R., Hood, F. J. C., Bradnum, P., Thoragonnet, D. \& Selkon, J. B. (1977) Metronidazole compared with penicillin in the treatment of acute dental infections. British Journal of Oral Surgery 14, 264-269.

Keyes, P., Wright, W. E., \& Howard, S. (1978) The use of phase contrast microscopy and chemotherapy in the diagnosis and treatment of periodontal lesions-Initial Report. Quint. Internat. Report 1590, Jan.-Feb. 1978, 1-14.

Knowles, J. W., Burgett, F. G., Nissle, R. R., Shick, R. A., Morrison, E. C. \& Ramfjord, S. P. (1979) Results of periodontal treatment related to pocket depth and attachment level. Journal of Periodontology 50, 225-233.

Kornman, K. S. \& Loesche, W. J. (1980) The subgingival microbial flora during pregnancy. Journal of Periodontological Research 15, 111-122.

Lindhe, J. \& Nyman, S. (1975) The effect of plaque control and surgical pocket elimination on the establishment and maintenance of periodontal health. Journal of Clinical Periodontology 2, 67-79.

Lindhe, J., Heijl, L., Goodson, J. M. \& Socransky, S. S. (1979) Local tetracycline delivery using hollow fiber devices in periodontal therapy. Journal of Clinical Periodontology 6, 141-149.

Listgarten, M. A. \& Lewis, D. W. (1967) The distribution of spirochetes in the lesion of acute necrotizing ulcerative gingivitis: an electron microscopic and statistical survey. Journal of Periodontology 38, 379-386.

Listgarten, M. A. \& Helldén, L. (1978) Relative distribution of bacteria at clinicalfy healthy and periodontally diseased sites in humans. Journal of Clinical Periodontology 5, 115132.

Listgarten, M. A., Mao, R. \& Robinson, P. J. (1976) Periodontal probing and relationship 
of the probe tip to periodontal tissues. Journal of Periodontology 47, 511-513.

Listgarten, M. A., Lindhe, J. \& Helldén, L. (1978) Effects of tetracycline and/or scaling on human periodontal disease. Journal of Clinical Periodontology 5, 246-271.

Löe, H. \& Shiott, C. R. (1970) The effect of mouthrinses and topical application of chlorexidine on the development of dental plaque and gingivitis in man. Journal of Periodontological Research 5, 79-83.

Loesche, W. J. (1976a) Chemotherapy of dental plaque infections. Oral Sciences Reviews 9, 63-105.

Loesche, W. J. (1976b) Periodontal disease and the treponemes. In The biology of parasitic spirochetes. (R. C. Johnson, ed.) pp. 261275. New York: Academic Press.

Loesche, W. J. (1979) Clinical and microbiclogical aspects of chemotherapeutic agents used according to the specific plaque hypothesis. Journal of Dental Research 58, 24042412.

Loesche, W. J. \& Nafe, D. (1973) Reduction of supragingival plaque accumulations in institutionalized Down's Syndrome patients by periodic treatment with topical kanamycin. Archieves of Oral Biology 18, 1131-1144.

Loesche, W. J. Syed, S. A. (1978) Bacteriology of human experimental gingivitis: effect of placue and gingivitis score. Infections and Immunity 21, 830-839.

Loesche, W. J., Hockett, R. N. \& Syed, S. A. (1972) The predominant cultivable flora of tooth surface plaque removed from institutionalized subjects. Archives of Oral Biology 17, 1311-1326.

Loesche, W. J., Paunio, K. V., Woolfolk, M. P. \& Hockett, R. N. (1974) Collagenolytic activity of dental plaque associated with periodontal pathology. Infections and Immunity 9, 329-336.

Lozdan, J., Sheiham, A., Pearlman, B. A., Kreiser, B., Rachanis, C. C. \& Meyer, P. (1971) The use of nitrimadazine in the treatment of acute ulcerative gingivitis. A doubleblind controlled trial. British Dental Journal 130, 294-301.

MacDonald, J. B., Socransky, S. S. \& Gibbons, R. J. (1963) Aspects of the pathogenesis of mixed anaerobic infections of mucous membranes. Journal of Dental Research 42, 529545.

Mühlemann, H. R. \& Son, S. (1971) Gingival sulcus bleeding - a leading symptom in initial gingivitis. Helvetica Odontologica Acta 15 107-113.

Muller, M., Lindmark, D. G. \& McLaughlin, J. (1977) Mode of action of metronidazole on anaerobic microorganisms. In Metronidazole (S. Finegold, ed.) Proceedings of the International Metronidazole Conference, Montreal, Quebec, Canada, May 26-28, 1976. Excerpta Medica, 12-19.

Newman, M. G. \& Socransky, S. S. (1977) Predominant cultivable microbiota in periodontosis. Journal of Periodontal Research 12, $120-128$.

Nyman, S., Lindhe, J. \& Rosling, B. (1978) Periodontal surgery in plaque-infected dentitions. Journal of Clinical Periodontology 5, 240-249.

Osterberg, S. K. A., Williams, B. L. \& Jorgensen, J. (1979) Long-term effects of tetracycline on the subgingival microflora. Journal of Clinical Periodontology 6, 133-140.

Ramfjord, S. P. (1967) The periodontal disease index. Journal of Periodontology 38, 602608.

Roe, F. J. C. (1977) Metronidazole: Tumorigenicity studies in mice, rats, and hamsters. In Metronidazole (S. Finegold, ed.) Proceedings of the International Metronidazole Conference, Montreal, Quebec, Canada, May 2628, 1976. Excerpta Medica, 132-137.

Rosenkranz, H. S. \& Speck, W. T. (1977) Studies on the significance of the mutagenicity of metronidazole for Salmonella typhimurium. In Metronidazole (S. Finegold, ed.) Proceedings of the International Metronidazole Conference, Montreal, Quebec, Canada, May 26-28, 1976. Excerpta Medica, 119-125.

Rosling, B., Nyman, S. \& Lindhe, J. (1976a) The effect of systematic plaque control on bone regeneration in infrabony pockets. Journal of Clinical Periodontology 3, 38-53.

Rosling, B. Nyman, S., Lindhe, J. \& Jern, B. (1976b) The healing potential of the periodontal tissues following different techniques of periodontal surgery in plaque-free dentitions. Journal of Clinical Periodontology 3, 233-255.

Rust, J. H. (1977) An assessment of metronidazole tumorigenicity: studies in the mouse and rat. In Metronidazole (S. Finegold, ed.) Proceedings of the International Metronidazole Conference, Montreal, Quebec, Canada, May 26-28, 1976. Excerpta Medica, 138-144.

Rustia, M. \& Shubik, P. (1972) Induction of lung tumors and malignant lymphomas in 
mice by metronidazole. Journal of the $\mathrm{Na}$ tional Cancer Institute 48, 721-726.

Shinn, D. L. S. (1962) Metronidazole in acute ulcerative gingivitis. Lancet 1, 1191.

Shinn, D. L. (1977) Vincent's disease and its treatment. In Metronidazole (S. Finegold, ed.) Proceedings of the International Metronidazole Conference, Montreal, Quebec, Canada, May 26-28, 1976. Exerpta Medica, 334-340.

Slots, J. (1977) The predominant cultivable microflora of advanced periodontitis. Scandinavian Journal of Dentistry 85, 114-121.

Slots, J., Mashimo, P., Levine, M. J. \& Genco, R. J. (1979) Periodontal therapy in humans. I. Microbiological and clinical effects of a single course of periodontal scaling and root planning, and of adjunctive tetracycline therapy. Journal of Periodontology 50, 495509.

Socransky, S. S. (1977) Microbiology and periodontal disease - present status and future considerations. Journal of Periodontology 48, 497-504.

Socransky, S. S., Gibbons, R. J., Dale, A. C., Bortnick, L., Rosenthal, E., \& MacDonald, J. B. (1963) The microbiota of the gingival crevice area of man. I. Total microscopic and viable counts of specific organisms. Archives of Oral Biology 8, 275-280.

Sutter, V. L. \& Finegold, S. M. (1977) In vitro studies with metronidazole against anaerobic bacteria. In Metronidazole (S. Finegold, ed.)
Proceedings of the International Metronidazole Conference, Montreal, Quebec, Canada, May 26-28, 1976. Excerpta Medica, 279-285.

Syed, S. A. \& Loesche, W. J. (1978) Efficiency of Kontes ultrasonic cell disruptor in the dispersion of dental plaque and pure cultures of oral flora. Journal of Dental Research, Special Issue 57. IADR Abstract No. 982.

Syed, S. A. Svanberg, M. \& Svanberg, G. (1980) Predominant cultivable dental plaque flora of beagle dogs with gingivitis. Journal of Periodontal Research 15, 123-136.

Tanner, A. C. R., Hafer, C., Bratthall, G. T., Visconti, R. A. \& Socransky, S. S. (1979) A study of the bacteria associated with advancing periodontitis in man. Journal of Clinical Periodontology 6, 278-307.

Williams, B. L., Pantalone, R. \& Sherris, J. C. (1976) Subgingival microflora and periodontitis. Journal of Periodontal Research 11, $1-18$.

Williams, B., Osterberg, S. S. K. \& Jorgensen, J. (1979) Subgingival microflora of periodontal patients in tetracycline therapy. Journal of Clinical Periodontology 6, 210-221.

Address:

Walter J. Loesche

Room 3204, Dental School

University of Michigan

Ann Arbor, Michigan 48109

U.S.A. 
This document is a scanned copy of a printed document. No warranty is given about the accuracy of the copy. Users should refer to the original published version of the material. 